\title{
PENGARUH MODEL CONTEXTUAL TEACHING AND LEARNING \\ (CTL) DAN MOTIVASI BELAJAR TERHADAP KEMAMPUAN BERPIKIR KRITIS DALAM PEMBELAJARAN SEJARAH DI SMA DI KOTA MADIUN
}

\author{
Oleh: \\ Arfan Diansyah
}

\begin{abstract}
Abstrak
Penelitian ini bertujuan untuk melihat pengaruh penggunaan model Contextual Teaching and Learning (CTL) dan motivasi terhadap kemampuan berpikir kritis dalam pembelajaran sejarah di SMA Madiun. Metode Penelitian ini menggunakan metode eksperimen dengan disain faktorial $2 \times 2$. Populasi pada penelitian ini adalah peserta didik SMA negeri di kota Madiun dengan sampel penelitian adalah peserta didik kelas XI IS SMA Negeri 3 sebagai kelas eksperimen dan peserta didik kelas XI IS SMA Negeri 2 sebagai kelas kontrol tahun pelajaran 2013/2014. Jumlah sampel terdiri dari 30 peserta didik kelas eksperimen dan 30 peserta didik kelas kontrol. Teknik pengambilan sampel dengan menggunakan teknik sampling multi stage random sampling. Teknik pengumpulan data dengan menggunakan akngket (kuesioner) untuk variabel motivasi belajar dan test objektif untuk variabel kemampuan berpikir kritis. Uji hipotesis dilakukan dengan menggunakan uji Anova dua jalan (statistik parametrik). Hasil penelitian menunjukan bahwa : (1) Ada pengaruh model CTL terhadap kemampuan berpikir kritis dalam pembelajaran sejarah di SMA negeri di kota Madiun. (2) Ada pengaruh motivasi belajar terhadap kemampuan berpikir kritis dalam pembelajaran sejarah di SMA Negeri di kota Madiun. (3) tidak ada interaksi pengaruh antara model CTL dan motivasi belajar terhadap kemampuan berpikir kritis dalam pembelajaran sejarah di SMA Negeri di kota Madiun.
\end{abstract}

Kata Kunci : Belajar dan Pembelajaran Sejarah, Model Pembelajaran CTL, Motivasi Belajar, Kemampuan Berpikir Kritis. 


\section{PENDAhuluan}

Akhir-akhir ini, upaya menanamkan kemampuan berpikir kritis peserta didik menjadi popular dalam bidang pendidikan khususnya di Indonesia, namun gagasan demikian bertolak belakang dengan pelaksanaanya dibanyak sekolah diberbagai tempat. Dikelas, pembelajaran sejarah oleh peserta didik terkesan membosankan dan tidak bermakna. Salah satu fenomena yang sering muncul ketika proses pembelajaran sejarah berlangsung adalah lemahnya daya tarik peserta didik dalam mengikuti pelajaran sejarah. Peserta didik kurang memperhatikan atau bahkan mengantuk saat proses pembelajaran berlangsung. Salah satu yang menjadi penyebabnya adalah penggunaan model pembelajaran yang tidak sesuai dengan kebutuhan peserta didik. penggunaan model pembelajaran yang konvensional misalnya, dalam model ini, peserta didik dijadikan sebagai objek pembelajaran dan bukan sebagai subjek. Peserta didik hanyalah sebagai transfer pasif informasi atau materi sejarah yang disajikan. Sehingga peran siswa tidak tampak dalam kegiatan pembelajaran.

Critical thinking entails effective communication and problem solving abilities as well as a commitment to overcome our native egocentrism and sociocentrism (Paul Further dalam Justin Barry and Dr. Kate Scantlebury dalam jurnal Education 535.2010), artinya; dalam berpikir kritis memerlukan komunikasi yang efektif dan kemampuan memecahkan masalah serta komitmen untuk mengatasi egosentrisme dan sociocentrism yang kita miliki. Dalam berpikir kritis maka individu sebagai pemikir kritis meneliti dengan cermat proses berpikir mereka dari apa yang menjadi informasi yang mereka terima untuk mendapatkan pemahaman yang mendalam dan sebaikbaiknya. Dengan kemampuan dalam berpikir ketingkat yang lebih tinggi (kritis) tentu saja secara simultan akan semakin meningkatkan daya pikir dan mengubah serta memgkonstruk pengetahuan peserta didik tersebut yang tentunya kearah pemikiran yang memiliki banyak sudut pandang.

Pada hakekatnya belajar merupakan suatu proses memanusiakan manusia. Dimana lewat belajar maka manusia akan mencapai kesempurnaan baik perubahan sikap maupun pengetahuannya. Pembelajaran sejarah yang diimplementasikan secara 
baik, tidak saja dapat mengembangkan kemampuan ranah kognitif pada peserta didik, melainkan juga mengembangkan ranah apektif, bahkan ranah psikomotorik (G. Moedjanto,1986:6). Pembelajaran sejarah yang baik juga dapat mendorong peserta didik untuk berpikir kritis. Kemampuan Berpikir kritis , dapat menuntun peserta didik untuk memahami makna sejarah, baik sejarah nasional maupun umum (Aman.2011:110).

Pembelajaran sejarah menurut Djoko Suryo (2005:4) adalah merupakan suatu kegiatan mengembangkan kemampuan intelektual dan keterampilan untuk memahami proses perubahan dan keberlanjutan dan berfungsi sebagai sarana untuk menanamkan kesadaran akan adanya perubahan dalam kehidupan masyarakat melalui dimensi waktu. Aktivitas belajar dengan memusatkan pada peran siswa secara aktif, khususnya dalam pembelajaran sejarah akan sangat membantu dalam meningkatkan kemampuan berpikir kritis siswa. Pandangan konstruktivisme yang memusatkan pada peran siswa untuk membentuk struktur pengetahuannya sendiri memberikan gambaran bahwa tugas guru dalam pembelajaran sejarah harus mampu membangun situasi sedemikian rupa sehingga peserta didik terlibat secara aktif untuk mengkonstruksi pengetahuan mereka. Jika aktivitas pembelajaran sejarah dikelas melibatkan peran aktif siswa, maka dengan demikian terjadi peningkatan kemampuan berpikir kritis peserta didik itu sendiri.

Tidak tampaknya peran siswa dalam pembelajaran menjadikan kurangnya semangat peserta didik dalam belajar. Peserta didik telah terbiasa untuk hanya menerima informasi yang disampaikan oleh guru tanpa harus terlebih dahulu mengkontruksi informasi tersebut melalui struktur kognitifnya. Konsekuensinya adalah peserta didik tidak terlatih untuk memberikan argumen, penalaran, dan penyimpulanan dari sebuah informasi, khususnya materi sejarah. Padahal, kegiatan berpikir kritis harus berjalan melalui argumentasi, penalaran, dan penyimpulan (Benyamin Molan, 2012:13). Jika demikian, secara kuantitas kognitif akademik, peserta didik hanya dapat menghafal isi materi tanpa memami atau memaknai materi yang dipelajarinya. Tentu saja secara personal melalui tindakanya, peserta didik 
dengan kemampuan menghafal isi materi tanpa memahaminya dapat lebih mudah kehilangan arah tujuan dalam pusaran gobalisasi.

Contexstual Teaching and Learning (CTL) merupakan suatu sistem pembelajan dalam pendidikan yang melakukan lebih dari pada sekedar menuntun para peserta didik dalam belajar. Menurut Elaine B. Johnson (2011:67), bahwa Sistem CTL adalah sebuah proses pendidikan yang bertujuan menolong para peserta didik melihat makna didalam materi akademik yang mereka pelajari dengan cara menghubungkan subjeksubjek akademik dengan konteks keadaan pribadi, sosial, dan budaya mereka. Senada dengan itu, menurut Trianto (2008:10), Contextual Teaching and Learning merupakan konsep belajar yang membantu guru mengaitkan antara materi yang diajarkan dengan situasi dunia nyata peserta didik dan mendorong peserta didik membuat hubungan antara pengetahuan yang dimilikinya dengan penerapannya dalam kehidupan mereka sebagai anggota keluarga dan masyarakat.

Penerapan model pembelajaran kontektual meliputi : (1) Konstruktivisme (Contructivism); (2) Inkuiri (Inquiry); (3) Bertanya (Questioning); (4) Masyarakat belajar (Learning Community); (5) Pemodelan (Modelling); (6) Refleksi (Reflection); (7) Penilaian sebenarnya (Authentic Assesment), (Depdiknas: 2005:10). Sarwiji Suwandi (2004:1) berpendapat bahwa ada suatu pandangan yang menyatakan bahwa anak akan belajar lebih baik melalui kegiatan mengalami sendiri dalam lingkungan yang alamiah. Dengan demikian ketujuh komponen tersebut, jika diterapkan dalam pembelajaran sejarah, maka pembelajaran akan dirasa bermakna.

Selain model pembelajaran CTL, motivasi sangatlah penting dalam mengasah kemampuan berpikir kritis peserta didik. Menurut Gagne (1976 ; 189), motivasi merupakan kekuatan dari dalam termasuk sifat ingin tahu dan usaha penyelidikan. Senada dengan pendapat diatas, Schunk (2012:475) mengatakan bahwa motivasi adalah proses mendorong dan mempertahankan tujuan dengan mengarahkan perilaku. Sifat ingin tahu yang menjadi salah satu ciri seseorang yang memiliki motivasi dalam belajar tersebut dalam hal ini didorong oleh sebuah proses berpikir dan usaha untuk mencapai tujuan. Sejalan dengan pendapat tersebut diatas, menurut M. Neil Browne 
$(2012 ; 16)$ salah satu nilai utama seorang pemikir kritis adalah keingintahuan. Dengan demikian dapat dijelaskan bahwa untuk menjadi seorang pemikir kritis, individu harus bertanya-tanya tentang apa yang telah dijumpainya. Dalam pengertian lain individu haruslah mempertanyakan sejumlah informasi yang diterimanya. Kegiatan bertanya dan rasa ingin tahu tersebut diatas didasari oleh adanya motivasi belajar yang tinggi dalam diri peserta didik.

Secara umum motivasi merupakan sebuah perubahan energi dalam diri (individu) yang ditandai dengan timbulnya perasaan dan reaksi atas dasar untuk mencapai sebuah tujuan. Menurut Santrock (2009: 199), Motivasi merupakan sesuatu yang melibatkan proses yang memberikan energi, mengarahkan, dan mempertanyakan perilaku. Dengan demikian perilaku yang termotivasi dalah perilaku yang mengandung energi, memiliki arah, dan dapat dipertahankan. Motivasi belajar merupakan sebuah kekuatan untuk mendorong peserta didik melakukan sesuatu dengan maksud mencapai sebuah tujuan. Dengan demikian guru harus mampu meningkatkan motivasi belajar peserta didik , lewat tindakan mengetahui kebutuhan peserta didik, merancang model pembelajaran yang tepat dengan mengidentifikasi karakteristik dan kebutuhan peserta didik tersebut. Perencanaan dan model yang baik, pada akhirnya akan mampu meningkatkan motivasi belajar peserta didik.

Permasalahan dalam penelitian ini dirumuskan sebagai berikut : (1) apakah ada pengaruh model CTL terhadap kemampuan berpikir kritis peserta didik ? (2) apakah ada pengaruh motivasi belajar terhadap kemampuan berpikir kritis peserta didik ? (3) apakah ada interaksi pengaruh antara model CTL dan motivasi belajar terhadap kemampuan berpikir kritis peserta didik?

Tujuan penelitian ini adalah untuk menganalisis (1) pengaruh model CTL terhadap kemampuan berpikir kritis peserta didik, (2) pengaruh motivasi belajar terhadap kemampuan berpikir kritis peserta didik, (3) interaksi pengaruh model CTL dan motivasi belajar terhadap kemampuan berpikir kritis peserta didik.

Dari berbagai penjelasan diatas mengenai belajar dan pembelajaran sejarah, model pembelajaran CTL, motivasi belajar, dan kemampuan berpikir kritis peserta 
didik, diduga bahwa (1) ada pengaruh model CTL terhadap kemampuan berpikir kritis peserta didik, (2) ada pengaruh motivasi belajar terhadap kemampuan berpikir kritis, (3) ada interaksi pengaruh antara model CTL dan motivasi belajar terhadap kemampuan berpikir kritis.

Penelitian ekperimen ini berlokasi di SMA Negeri di kota Madiun dengan sampel penelitian adalah peserta didik SMA Negeri 3 kota madiun sebagai kelas ekperimen dan SMA Negeri 2 kota Madiun sebagai kelas kontrol. Proses penelitian dilaksanakan pada bulan November tahun 2012, dihitung sejak pembuatan proposal penelitian. Adapun pelaksanaan penelitian dilakukan pada bulan April tahun 2013.

Dalam penelitian ini, disain yang digunakan adalah disain eksperimen faktorial $2 \times 2$. Disain faktorial ini, masing-masing dari kedua variabel bebas itu mempunyai dua nilai. Pertama, variabel eksperimental (variabel bebas yang dimanipulasi). Kedua, variabel atribut yang telah dibagi menjadi dua tingkat (tinggi dan rendah). Pengaruh perlakuan eksperimental pokok terhadap variabel terikat dinilai pada setiap tingkatan variabel yang lain.

Pengambilan sampel dilakukan dengan menggunakan multi-stage random sampling dengan tahapan sebagai berikut : (1) memilih sekolah ; dari beberapa sekolah SMA Negeri di Kota Madiun dipilih 2 sekolah dalam kategori yang sama, yaitu samasama SMA Negeri yang dipandang memiliki kualitas yang sama. (2) memilih tingkat kelas ; tingkatan kelas yang ada terdiri kelas XI IS di SMA N 3 Madiun, kelas XI IS di SMA N 2 Madiun dengan pertimbangan disesuaikan dengan SKKD yang akan dipakai untuk menerapkan pembelajaran dengan model CTL dan model ekspositori yaitu dikelas XI IS. kelas IS (Ilmu Sosial) merupakan kelas penjurusan yang lebih banyak menerima materi pelajaran Sejarah dibandingkan dengan kelas IA (Ilmu Alam).

Sumber data diperoleh dari data kemampuan berpikir kritis dari hasil kegiatan pembelajaran sejarah dikelas yang diajarkan dengan model CTL dan ekspositori yang ditinjau dari motivasi belajar yang dimiliki oleh masing-masing peserta didik. Secara operasional, nilai kemampuan berpikir kritis peserta didik adalah skor yang diperoleh oleh peserta didik dalam menjawab butir soal yang diberikan. Instrumen yang 
dikembangkan untuk mengukur kemampuan berpikir kritis peserta didik adalah dalam bentuk tes objektif yang meliputi : (1) kemampuan menganalisis informasi yang disampaikan; (2) melihat kesimpulan dari sebuah informasi; dan (3) memahami implikasi dari sebuah informasi yang disampaikan. Sedangkan untuk variabel motivasi dilakukan dengan menggunakan angket (kuesioner) yang meliputi : (1) keinginan untuk berhasil dalam belajar ; (2) keinginan untuk meningkatkan kemampuan berpikir kritis ; dan (3) rasa percaya diri dan kepuasan.

Sebelum dilakukan tes pada kelas eksperimen (CTL) dan kelas kontrol (Ekspositori), dilakukan terlebih dahulu uji coba instrumen yang meliputi instrumen motivasi belajar dan kemampuan berpikir kritis. Data hasil uji coba Instrumen diperoleh dari peserta didik Kelas XI IS di SMA Negeri 1 Kota Madiun. Berdasarkan hasil perhitungan uji validitas instrumen motivasi belajar dengan menggunakan SPSS 16 dengan rumus korelasi Pearson Correlation diketahui bahwa butir kuesioner yang valid berjumlah 33 butir dari 40 butir kueisioner serta reliabilitas yang diuji dengan rumus formula Alphasebesar 0.896. Sementara itu, uji validitas instrumen kemampuan berpikir kritis dengan menggunakan program SPSS 16 dengan rumus Spearman Correlation, diketahui bahwa butir soal yang valid adalah berjumlah 24 butir dari 30 butir soal, serta reliabilitas yang diuji dengan rumus formula Alpha sebesar 0.816.

Pada instrumen kemampuan berpikir kritis, Tingkat kesulitan soal disimbolkan dengan ( p ) dan daya beda atau diskriminasi soal disimbolkan dengan ( d ). Tingkat kesulitan soal adalah proporsi tes yang menjawab benar butir soal tersebut. Setelah diperoleh nilai $\mathrm{p}$ dari hasil perhitungan lalu diadakan interpretasi dengan mengkonsultasikannya pada tabel indeks kesukaran soal yaitu ; $0.00-0.30$ (sukar), 0.30 - 0.70 (sedang), dan 0.70 - 1.00 (mudah) (Saefudin Azwar, 2011:134). Dari hasil analisis terdapat 5 soal pada kategori sukar, pada kategori sedang terdapat 12 butir, dan kategori mudah terdapat 7 butir. Daya beda merupakan proporsi menjawab item benar antara kelompok tinggi dan kelompok rendah. Setelah diperoleh nilai $d$ dari hasil perhitungan lalu diadakan interpretasi dengan mengkonsultasikannya pada tabel indeks daya beda yaitu ; 0.40 atau lebih (bagus sekali), 0.30 - 0.39 (lumayan bagus), 0.20 - 
0.29 (belum memuaskan dan perlu diperbaiki), kurang dari 0.20 (jelek dan harus dibuang) yang diadaptasi dari Ebel dalam Saefudin Azwar (2011:140). Setelah dilakukan perhitungan daya diskriminasi butir soal, diperoleh 4 butir soal pada kategori jelek dan harus dibuang dan terdapat 9 butir soal yang harus diperbaiki.

Sebelum melakukan uji hipotesis, terlebih dahulu dilakukan uji persyaratan analisis variansi (anova) berupa uji normalitas data dan uji homogenitas data (Budiono,2009:185). Uji Normalitas dilakukan untuk mengetahui apakah populasi berdistribusi normal. Uji homogenitas dimaksudkan untuk mengetahui apakah populasi mempunyai variansi yang sama atau tidak. Uji hipotesis dilakukan untuk mengetahui apakah hipotesis dalam penelitian diterima atau ditolak. Dalam penelitian ini uji hipotesis menggunakan analisis variansi (anava) dua jalan. Jika terdapat interaksi pengaruh antara variabel model CTL dan motivasi belajar, maka dilanjutkan dengan uji Scheffe akan tetapi jika tidak terdapat interaksi dari kedua variabel tersebut diatas, maka tidak perlu dilakukan uji lanjut pasca Anova atau uji Scheffe (Budiono, 2009:215).

\section{PEMBAHASAN}

Analisis deskriftif data hasil penelitian berupa perhitungan distribusi frequensi dari delapan kelompok data. Distribusi frekuensi masing-masing kelompok data dijabarkan pada tabel 1 berikut ini :

Tabel 1. Distribusi frequensi

\begin{tabular}{|c|c|c|c|c|}
\hline Kelompok & A1 & A2 & B1 & B2 \\
\hline Mean & 80.77 & 68.07 & 81.28 & 66.57 \\
\hline Median & 81.00 & 71.00 & 83.00 & 67.00 \\
\hline Mode & 75 & 58 & 83 & 58 \\
\hline Std.Deviation & 8.303 & 8.497 & 7.445 & 7.608 \\
\hline Variance & 68.944 & 72.202 & 55.434 & 57.884 \\
\hline Range & 29 & 29 & 25 & 25 \\
\hline
\end{tabular}




\begin{tabular}{|c|l|l|l|l|}
\hline Minimum & 67 & 54 & 71 & 54 \\
\hline Maximum & 96 & 83 & 96 & 79 \\
\hline
\end{tabular}

\begin{tabular}{|c|c|c|c|c|}
\hline Kelompok & A1B1 & A1B2 & A2B1 & A2B2 \\
\hline Mean & 85.16 & 73.18 & 75.62 & 62.29 \\
\hline Median & 83.00 & 75.00 & 75.00 & 63.00 \\
\hline Mode & 83 & 67 & 71 & 58 \\
\hline Std.Deviation & 6.517 & 4.854 & 4.574 & 5.785 \\
\hline Variance & 42.474 & 23.564 & 20.923 & 33.471 \\
\hline Range & 21 & 12 & 12 & 21 \\
\hline Minimum & 75 & 67 & 71 & 54 \\
\hline Maximum & 96 & 79 & 83 & 75 \\
\hline
\end{tabular}

Keterangan :

A1 = Data kemampuan berpikir kritis kelas CTL

A2 = Data kemampuan berpikir kritiskelas ekspositori

B1 = Data kemampuan berpikir kritisdengan motivasi belajar tinggi

B2 = Data kemampuan berpikir kritis dengan motivasi belajar rendah

A1B1 = Data kemampuan berpikir kritis kelas CTL dan motivasi belajar tinggi

A1B2 = Data kemampuan berpikir kritis kelas CTL dan motivasi belajar rendah

A2B1 = Data kemampuan berpikir kritis kelas ekspositori dan motivasi belajar tinggi

A2B2 = Data kemampuan berpikir kritis kelas ekspositori dan motivasi belajar rendah

Dalam penelitian ini uji normalitas dilakukan dengan menggunakan bantuan

SPSS 16 dengan menu analisis yang digunakan adalah uji Kolmogorov Sminov. $\mathrm{H}_{0}$ dengan menggunakan uji ini dinyatakan sebagai sampel berasal dari populasi yang berdistribusi normal, sedangkan $\mathrm{H}_{1}$ dinyatakan sebagai sampel tidak berasal dari populasi yang berdistibusi normal. Dasar pengambilan keputusan dilakukan dengan melihat angka probalitas dengan ketentuan $\mathrm{H}_{0}$ diterima jika "probalitas sig. $>0.05$ ", sedangkan $\mathrm{H}_{0}$ ditolak jika "probalitas sig. $<0.05$ ". Pengujian normalitas data pada penelitian ini dilakukan terhadap delapan kelompok data yaitu $A_{1}, A_{2}, B_{1}, B_{2}, A_{1} B_{1}$, $\mathrm{A}_{1} \mathrm{~B}_{2}, \mathrm{~A}_{2} \mathrm{~B}_{1}, \mathrm{~A}_{2} \mathrm{~B}_{2}$. 
Berdasarkan hasil perhitungan yang dilakukan dengan SPSS 16 dengan menu analisis menggunakan uji Kolmogorov Sminov, diperoleh hasil bahwa semua kelompok data dalam penelitian ini berasal dari populasi yang berdistribusi normal. Hasil analisis normalitas data dapat dilihat dapat dilihat pada tabel 2 berikut ini ;

Tabel 2. Uji Normalitas

\section{One-Sampel Kolmogorov-Smirnov Test}

\begin{tabular}{|c|c|c|}
\hline Kelompok & $\begin{array}{l}\text { Kolmogorov- } \\
\text { Smirnov Z }\end{array}$ & $\begin{array}{l}\text { Asymp.Sig. } \\
\text { (2-tailed) }\end{array}$ \\
\hline A1 & 0.674 & 0.755 \\
\hline A2 & 0.922 & 0.363 \\
\hline B1 & 0.816 & 0.518 \\
\hline B2 & 0.824 & 0.505 \\
\hline A1B1 & 0.696 & 0.717 \\
\hline A1B2 & 0.635 & 0.815 \\
\hline A2B1 & 0.823 & 0.508 \\
\hline A2B2 & 0.996 & 0.274 \\
\hline
\end{tabular}

Uji Homogenitas Homogenitas data dilakukan terhadap keempat kelompok data, yaitu A1B1, A2B2, A2B1,A2B2. dengan menggunakan program SPSS 16 dengan menu analisis Levene test of homogeneity of variance menghasilkan nilai Levene Statistic sebesar 0.579, dengan probalitas untuk Levene test sig. $=0.632$. Dengan demikian probalitas sig.0.632>0.05, sehingga tidak dapat menolak hipotesis nol yang menyatakan populasi-populasi homogen. Hasil perhitungan homogenitas data dapat dilihat pada tabel 3 dibawah ini :

Tabel 3. Uji Homogenitas

\section{Test of Homogeneity of Variances}

Kemampuan Berpikir Kritis

\begin{tabular}{|r|r|r|r|}
\hline $\begin{array}{c}\text { Levene } \\
\text { Statistic }\end{array}$ & df1 & \multicolumn{1}{c|}{ df2 } & \multicolumn{1}{c|}{ Sig. } \\
\hline .579 & 3 & 56 & .632 \\
\hline
\end{tabular}


Karena seluruh data telah berdistribusi normal dan homogen, maka pengujian hipotesis layak dilakukan dengan analisis variansi (anova) dua Jalan. Dasar pengambilan keputusan " $\mathrm{H}_{0}$ ditolak jika $\mathrm{F}_{\text {obs }}$ berada di daerah kritis dengan $\mathrm{DK}=\{\mathrm{F} \mid \mathrm{F}$ $>\mathrm{F}_{0.05 ; \mathrm{df} ; \mathrm{n}}$ (Budiono, 2009 : 219). Hasil uji Anova dua Jalan secara keseluruhan telah terangkum pada tabel hasil ANAVA yang disajikan berikut ini :

Tabel 4. Rangkuman Anava Dua Jalur

\section{Tests of Between-Subjects Effects}

Dependent Variable:Kemampuan Berpikir Kritis

\begin{tabular}{|l|l|l|l|l|l|}
\hline Source & Df & $\begin{array}{l}\text { Mean } \\
\text { Square }\end{array}$ & F & Sig. & $\begin{array}{l}\text { P.E } \\
\text { Square }\end{array}$ \\
\hline MP & 1 & 2419.35 & 75.82 & 0.000 & 0.575 \\
\hline MB & 1 & 2299.98 & 72.08 & 0.000 & 0.563 \\
\hline MP*MB & 1 & 6.479 & 0.20 & 0.654 & 0.004 \\
\hline
\end{tabular}

Keterangan :

MP = Model Pembelajaran

$\mathrm{MB}=$ Motivasi Belajar

MP*MB = Interaksi Model Pembelajaran dan Motivasi Belajar

Hasil pengujian hipotesis pertama dengan menggunakan anava dua jalan diperoleh nilai $F_{\text {hitung }}=75.826$, sedangkan $F_{\text {tabel }}=4.00$, sehingga $F_{\text {hitung }}>F_{\text {tabel }}$ atau $75.826>4.00$. dengan demikian dapat dikatakan bahwa ada pengaruh model pembelajaran terhadap kemampuan berpikir kritis peserta didik. Dari hasil analisis distribusi frequensi terlihat bahwa peserta didik yang diajarkan dengan model Contextual Teaching and Learning (CTL) memiliki nilai rata-rata lebih tinggi (Mean = 80.77) dibandingkan dengan rata-rata kemampuan berpikir kritis peserta didik yang diajarkan dengan model ekspositori $($ Mean $=68.07)$. Hasil ini menandakan bahwa model CTL lebih efektif dibandingkan dengan model ekspositori. Jadi kesimpulan untuk hipotesis pertama adalah ada pengaruh positif dan signifikan model Contextual Teaching and Learning (CTL) terhadap kemampuan berpikir kritis peserta didik dalam pembelajaran sejarah di SMA Negeri di Kota Madiun. 
Berpikir kritis adalah pemikiran yang masuk akal dan reflektif yang berfokus untuk memutuskan apa yang mesti dipercaya atau dilakukan (Norris dan Ennis dalam Fisher, 2008:4). Suatu yang dapat diterima secara umum bahwasanya kemampuan berpikir kritis merupakan sebuah kemampuan untuk menganalisis, memilih argumen logis, serta menyimpulkan dan memahami implikasi dari sebuah informasi yang disampaikan. Sebuah pemikiran yang kritis sangat dibutuhkan dalam dunia akademi serta kehidupan sehari-hari.. Pandangan ini didasarkan pada suatu pengertian bahwa ilmu pengetahuan selalu berkutat pada kebenaran-kebanaran ilmiah berupa tesis, dan hipotesis, yang akan dijadikan dasar pengandaian (Benyamin Molan, 2012:12). Oleh karena itu, kemampuan berpikir kritis dapat dijadikan sebagai alat untuk menguji kebenaran-kebenaran ilmiah dan validitasnya dari rekontruksi pengetahuan tersebut secara ilmiah.

Dalam CTL, hakikat pembelajaran konstruktivisme itu sendiri, pada prakteknya menyarankan kepada guru agar mengembangkan pemikiran peserta didik untuk mencari makna, bekerja sendiri, menemukan sendiri, dan mengkonstruksi sendiri pengetahuan dan keterampilan barunya. Pengetahuan terbentuk oleh dua faktor penting, yaitu objek yang menjadi bahan pengamatan dan kemampuan subjek untuk mengiterpretasi objek tersebut (Wina Sanjaya, 2012:265), dengan demikian kognisi seseorang berkembang bukan karena menerima pengetahuan dari luar secara pasif tetapi orang tersebut secara aktif mengkonstruksi pengetahuannya (Yudrik Yahya, 2011:120). Penggunaan analogi-analogi telah diusulkan sebagai salah satu cara memperkuat pengajaran keterampilan berpikir didalam pelajaran-pelajaran yang konstruktivis (English, dalam Daniel Muits, 2008:194).

Kegiatan inkuri menyarankan sebuah proses pembelajaran yang berbasis penemuan masalah. Menurut Kuhn dalam Michelle M. Vine (International Journal for the Scholarship of Teaching and Learning : 2011) dinyatakan bahwa "Research has demonstrated that the positive learning outcomes of Inquiry skill development include critical thinking, the ability to undertake independent inquiry, and responsibility for their own learning, intellectual growth, and maturity"(Hasil penelitian menunjukan 
pembelajaran yang positif dari pengembangan keterampilan inkuiri, termasuk didalamnya berpikir kritis, kemampuan untuk melakukan penyelidikan, tanggung jawab untuk belajar mandiri, pertumbuhan intelektual serta kematangan).

Kegiatan bertanya dimaksudkan untuk mengembangkan rasa ingin tahu siswa. Dengan memberikan berbagai pertanyaan maka peserta didik diajarkan untuk menggunakan nalar dalam menindaklanjuti informasi yang masuk. Kegiatan pembelajaran tanpa pertanyaan merupakan sebuah kegiatan mematikan komunikai (komunikasi satu arah). Matinya komunikasi ini melemahkan keingintahuan siswa, yang sebenarnya bertentangan dengan salah satu nilai-nilai pemikiran kritis yaitu keingintahuan (M. Neil Browne, 2012:23).

Diskusi kelompok merupakan suatu kegiatan untuk berbagi pengalaman dan gagasan. Kegiatan diskusi mendatangkan sebuah diferensiasi ide. Ide-ide tersebut kemudian oleh peserta didik dikembangkan menjadi struktur pengetahuan yang baru. Hasil temuan peserta didik merupakan yang benar menurut cara pandang masingmasing peserta didik. akan tetapi, melalui proses diskusi tersebut yang didalamnya terdapat berbagai macam argumentasi dari proses penalaran dan kesimpulan. Kebenaran-kebenaran tersebut secara terus menerus diuji sepanjang diskusi itu berlangsung. Dalam pada itu, untuk dapat bisa melakukan pengujian dengan baik, dan pada akhirnya sampai pada kebenaran yang sejati, kegiatan berpikir kritis harus berjalan melalui argumentasi, penalaran dan penyimpulan tersebut (Benyamin Molan, 2012:13).

Pemodelan merupakan suatu komponen dalam CTL dengan menghadirkan model dalam pembelajaran. Melalui modeling siswa dapat terhindar dari pembelajaran yang teoritis-abstrak yang dapat memungkinkan terjadinya verbalisme (Wina Sanjaya, 2012:268). Ketika para guru melibatkan murid dalam kegiatan fisik untuk mendukung suatu pelajaran ,maka peserta didik tersebut kemungkinan besar untuk mengingat apa yang mereka pelajari (Elaine B. Johson, 2009:57).

Refleksi menjadikan pengalaman belajar peserta didik akan direnungkan dan kemudian dimasukkan dalam struktur kognif peserta didik sehingga pada akhirnya 
akan membentuk pengetahuan baru pada peserta didik dalam proses pembelajaran dikelas dengan menggunakan model CTL dalam penelitian ini, guru memberikan kesempatan kepada siswa untuk merenung atau mengingat kembali materi yang telah mereka pelajari, memberikan kebebasan kepada siswa untuk menafsirkan pengalamannya berarti memberikan kesempatan kepada siswa untuk menyimpulkan mengenai pengalaman yang diperoleh dari hasil belajarnya.

Penilaian autentik mengajak para siswa untuk menggunakan pengetahuan akademik dalam konteks dunia nyata untuk tujuan yang bermakna serta mempertajam keahlian berpikir dalam tingkatan yang lebih tinggi saat mereka menganalisis, memadukan, serta mengidentifikasi masalah, menciptakan solusi, dan mengikuti hubungan sebab akibat (Elaine B. Johson, 2011:289).

Dalam pembelajaran dengan model ekspositori, aliran pskologi belajar yang terkandung dalam pembelajaran demikian adalah aliran belajar behavioristik (Wina Sanjaya, 2012:178). Belajar menurut behavioris adalah suatu yang dilakukan orang untuk merespon stimuli eksternal (Daniel Muijs, 2008:20). Belajar dengan pendekatan behaviorisme adalah belajar yang menekankan pada hasil bukan proses. Dalam praktiknya materi pelajaran disampaikan langsung oleh guru, siswa tidak diajak untuk menemukan materi tersebut. Keberhasilan dalam belajar dilihat dari apa yang telah peserta didik ungkapkan kembali dari materi yang telah diuraikan. Yudrik Yahya (2011:401) mengemukakan bahwa meningkatkan kecerdasan anak dapat dilakukan dengan cara bekerja sama dalam suatu kelompok. Dalam kelas ekspositori peserta didik tidak diberikan ruang untuk dilaksanakannya diskusi kelompok dalam pembelajaran. Berangkat dari teori dan praktik pembelajaran ekpositori tersebut diatas, tentu saja suasana pembelajaran demikian sedikit memberikan efek terhadap kemampuan berpikir kritis peserta didik.

Hasil pengujian hipotesis kedua dengan menggunakan anava dua jalan diperoleh nilai $F_{\text {hitung }}=72.085$, sedangkan $F_{\text {tabel }}=4.00$, sehingga $F_{\text {hitung }}>F_{\text {tabel }}$ atau $72.085>4.00$. dengan demikian dapat dikatakan bahwa ada pengaruh motivasi belajar terhadap kemampuan berpikir kritis peserta didik. 
Salah satu nilai utama seorang pemikir kritis adalah keingintahuan. Menurut M. Neil Browne (2012) nilai-nilai utama seorang pemikir kritis adalah kemandirian, keingintahuan, kerendahan hati, dan penghargaan untuk nalar yang baik. Dalam pada itu, Gagne (1976 ; 189), menerangkan bahwa motivasi merupakan kekuatan dari dalam termasuk sifat ingin tahu dan usaha penyelidikan. Motivasi adalah sebagai suatu proses yang memberikan semangat, arah, dan kegigihan perilaku (Jhon W. Santrock ,2010:510). Dalam konteks pembelajaran dikelas, rasa ingin tahu terlihat pada usaha, kemauan, keberanian individu untuk menanyakan informasi yang disampaikan pada saat pembelajaran berlangsung. Diluar kelas, rasa ingin tahu mendorong peserta didik untuk mencari lebih banyak lagi sumber-sumber informasi atau fakta-fakta untuk dijadikan sebagai bahan perbandingan atas informasi yang sebelumnya diterimah. Mengutip hasil penelitian Fyan dan Maehr dalam Agus Suprijono (2012:162), dari tiga faktor yang memengaruhi prestasi belajar yaitu latar belakang keluarga, kondisi dan konteks sekolah dan motivasi, maka faktor terakhir merupakan faktor yang paling baik. aktivitas demikian membantu individu untuk meningkatkan kemampuan berpikir kritis.

Hasil pengujian hipotesis ketiga dengan menggunakan anava dua jalan diperoleh nilai $F_{\text {hitung }}=0.203$, sedangkan $F_{\text {tabel }}=4.00$, sehingga $F_{\text {hitung }}<F_{\text {tabel }}$ atau $0.203<4.00$. dengan demikian dapat dikatakan bahwa tidak terdapat interaksi pengaruh model pembelajaran dan motivasi belajar terhadap kemampuan berpikir kritis peserta didik. Hal ini berarti tidak ada interaksi model Contextual Teaching and Learning (CTL) dan motivasi belajar terhadap kemampuan berpikir kritis dalam pembelajaran sejarah di SMA Negeri di Kota Madiun.

Model Contextual Teaching and Learning dan motivasi belajar berpengaruh terhadap kemampuan berpikir kritis. akan tetapi, pengaruh kedua variabel tersebut berjalan sendiri-sendiri. Hal ini dibuktikan dari hasil hipotesis ketiga dalam penelitian ini bahwa tidak danya interaksi pengaruh model CTL dan motivasi belajar terhadap kemampuan berpikir kritis peserta didik dalam pembelajaran sejarah di SMA Negeri di kota Madiun. Hasil ini sejalan dengan penelitian yang dilakukan oleh Wulan 
Kristiani (Tesis UNS Surakarta : 2010) yang menyatakan bahwa tidak terdapat pengaruh antara penerapan pembelajaran kontekstual dan motivasi belajar terhadap hasil belajar IPS Geografi.

\section{PENUTUP}

Berdasarkan hasil analisis dan pembahasan, maka dapat disimpulkan bahwa (1) pembelajaran model Contextual Teaching an Learning berpengaruh terhadap kemampuan berpikir kritis, (2) Motivasi belajar berpengaruh terhadap kemampuan berpikir kritis, (3) tidak terdapat interaksi pengaruh antara model CTL dan motivasi terhadap kemampuan berpikir kritis peserta didik. (4) pembelajaran dengan model CTL lebih baik dalam meningkatkan kemampuan berpikir kritis dari pada pembelajaran model ekspositori.Pembelajaran dengan model Contextual Teaching and Learning (CTL) dan Motivasi Belajar merupakan dua faktor yang penting dalam menunjang kemampuan berpikir kritis peserta didik. untuk itu maka seorang pendidik setidaknya memilih model pembelajaran CTL ini.

Selain itu juga seorang guru juga harus mampu menumbuhkan motivasi belajar peserta didik dengan kemampuan guru masing-masing. Dengan memfokuskan pada pembelajaran yang aktif, maka membuat pembelajaran menjadi menyenangkan, kurangnya rasa jemuh siswa, sehingga akan meningkatkan perhatian dan keseriusan siswa untuk memahami dan memaknai materi yang dipelajari. Diharapkan para guru untuk mencoba atau menerapkan model CTL ini dalam pembelajaran dikelas, untuk menunjang keberhasilan peserta didik dalam belajarnya.Pihak sekolah harus mampu memberikan lingkungan belajar yang menyenangkan, mengakomodir kegiatan individu untuk mengembangkan ide-ide positif. 


\section{DAFTAR BACAAN}

Aman. (2011). Model Evaluasi Pembelajaran Sejarah. Yogyakarta: Ombak Azwar, Saifudin. (2011). Tes Prestasi; Fungsi dan Pengembangan Pengukuran Prestasi Belajar. Yogyakarta : Pustaka Pelajar.

Barry, Justin, and Kate Scantleblury (2010). Using Writting in The Science Classroom to Develop Crittical Thinking Skills. Jurnal Education 535 University of Pennsylvania. http://www.sas.upenn.edu

Browne, Neil M. (2012). Pemikiran Kritis; Panduan untuk Mengajukan dan Menjawab Pertanyaan kritis. Jakarta: Indeks.

Budiyono, (2009). Statistika Untuk Penelitian. Surakarta : UNS Press

Depdiknas, (2005). Pendekatan Kontekstual (Contextual Teaching and Learning. Jakarta: Dirjendikdasmen.

Fisher, Alec. (2008). Berpikir Kritis; Sebuah Pengantar. Jakarta: Erlangga

Johnson, Elaine B . (2011). Contextual Teaching \& Learning ; Menjadikan Kegiatan Belajar-Mengajar Mengasyikkan dan Bermakna. Bandung : Kaifa Learning

Michelle M. Vine, dkk. (2011). “Inquiri Learning: Level, Discipline, Class Size, What Matters?". International Journal the Scholarship of Teaching and Learning, Vol.5, No.1, Georgia Southem University. Diakses http://www.georgiasouthem.edu/ijsotl

Moedjanto,G. (1986). Sejarah Sebagai Sarana Pendidikan Nilai Kebijaksanaan. Semarang: Makalah Seminar FPIPS IKIP Semarang.

Molan, Benyamin. (2012). "Logika; Ilmu dan seni Berpikir Kritis. Jakarta:Indeks

Muijs, Daniel dan Reynolds, David. (2008) Effective Teaching; Teori dan Aplikasi. Yogyakarta: Pustaka Pelajar.

Sanjaya, Wina. (2012). Strategi Pembelajaran Berorientasi Standar Proses Pendidikan. Jakarta : Kencana.

Santrock, John W. (2009). Psikologi Pendidikan. Jakarta : Salemba Humanika.

Schunk, Dale H. (2012). Learning Theories An Educational Persfektive. Yogyakarta : Pustaka Pelajar.

Suprijono, Agus. (2012). Cooperative Learning; Teori dan Aplikasi Paikem. Yogyakarta: Pustaka Pelajar

Suryo, Djoko.(2005). Paradigma Sejarah di Indonesia dan Kurikulum Sejarah; dalam makalah seminar nasional dan temu alumni PPS UNS. Surakarta : PPS UNS.

Suwandi, Sarwiji. (2004). "Penerapan Pendekatan Kontekstual (CTL) dalam Mengimplementasikan KBD. Jurnal Retorika Vol.2 UNS Surakarta.

Trianto. (2008). Mendesain Pembelajaran Kontekstual (CTL) di Kelas. Jakarta: Publisher.

Yahya, Yudrik. (2011). Psikologi Perkembangan. Jakarta: Kencana 